\title{
ANALISIS FAKTOR-FAKTOR YANG MEMPENGARUHI WAKTU TUNGGU PENGADAAN MATERIAL KONSTRUKSI PADA PROYEK GEDUNG DI KABUPATEN BADUNG
}

Putera Kumarayasa Mudita ${ }^{1}$, I K. Sudarsana ${ }^{2}$,Mayun Nadiasa ${ }^{2}$

\begin{abstract}
Abstrak: Dalam Pelaksanaan proyek konstruksi, kelancaran aliran material menuju lokasi proyek harus dijaga. Menunggu material yang sering terjadi akan menyebabkan dampak yang besar terutama untuk proyek skala besar yang menggunakan banyak tenaga kerja. Jika kedatangan material yang diperlukan tidak sesuai jadwal pengadaan material rencana, akan menyebabkan tenaga kerja tersebut menganggur sehingga biaya proyek akan membengkak serta terlambatnya waktu penyelesaian proyek. Penelitian ini dilakukan untuk mengetahui faktor-faktor yang mempengaruhi waktu tunggu pengadaan material konstruksi di Kabupaten Badung.

Data penelitian diperoleh dengan cara menyebarkan kuesioner terhadap 50 responden. Sample penelitian diperoleh dengan purposive sampling yaitu ditujukan pada para expert yang bekerja pada proyek gedung di Kabupaten Badung. Sebelum digunakan sebagai instrumen penelitian, kuesioner terlebih dahulu diuji validitasnya dengan korelasi Pearson Product-Moment dan reliabilitasnya dengan metode Alpha Cronbach. Pengolahan dan analisis data dilakukan dengan Analisis Faktor.

Hasil penelitian menunjukkan bahwa ada dua puluh empat variabel yang teridentifikasi mempengaruhi waktu tunggu pengadaan material konstruksi pada proyek gedung di kabupaten Badung. Semua variabel dapat dikelompokkan menjadi 7 faktor (Faktor I, II, III, IV, V, VI, VII). Faktor paling dominan ditinjau berdasarkan percent of variance adalah Faktor I yang terbentuk oleh enam variabel yaitu proses produksi material pada pemasok, relasi antara kontraktor dan pemasok, kurangnya stock material pada pemasok, ketersediaan alat angkut transportasi material, akses menuju proyek, dan kondisi topografi yang ekstrim.
\end{abstract}

Kata Kunci : Waktu Tunggu Pengadaan, Material Konstruksi, Analisis Faktor

\section{ANALYSIS OF FACTORS THAT INFLUENCE THE LEAD TIME OF CONSTRUCTION MATERIAL PROCUREMENT ON BUILDING PROJECTS IN THE BADUNG REGENCY}

\begin{abstract}
When undertaking construction projects, the smoothflow of materials to the project site must be maintained. Waiting for material, which frequently happens, will have a big impact, especially for large-scale projects that use a lot of labor. If the arrival of the materials is not in accordance with the schedule of material procurement planning, the workers will have nothing to do and the project cost will blow out and there will be delays in project completion time. This research investigates the factors which influence the lead time of construction material procurement in the Badung Regency.

Data was obtained by distributing a questionnaire to 50 respondents. A research sample was obtained by purposive sampling aimed at the experts who work on building projects in the Badung regency. Before being used as a research instrument, the questionnaire was tested for the validity of data by using the Pearson Product-Moment correlation and its reliability was tested using the Cronbach alpha method. Processing and data analysis was conducted by Factor Analysis.

The research results show there are twenty four variables identified that influence the lead time of construction material procurement on building projects in the Badung regency. All variables can be grouped into seven factors (Factor I, II, III, IV, V, VI, VII). The most dominant factor reviewed based on the percent of variance is Factor I which is formed by six variables being the material production process at the suppliers, the relationships between contractors and suppliers, a lack of material stock at the suppliers, the availability of material transportation, access to the project, and extreme topography.
\end{abstract}

Key Words : Procurement Lead Time, Construction Material, Factor Analysis

\footnotetext{
${ }^{1}$ Mahasiswa Program Magister Teknik Sipil, Program Pascasarjana Universitas Udayana

${ }^{2}$ Staf Pengajar Program Magister Teknik Sipil, Program Pascasarjana Universitas Udayana
} 


\section{PENDAHULUAN}

\section{Latar Belakang}

Proyek konstruksi terdiri dari berbagai aktivitas dan menggunakan berbagai sumber daya. Sumber daya tersebut diantaranya tenaga manusia atau pekerja, material/ bahan, dan alat-alat berat. Material merupakan salah satu sumber daya yang penting. Menurut Ervianto (2004), pemakaian material merupakan bagian terpenting yang mempunyai persentase cukup besar yaitu 50-70\% dari total biaya proyek. Oleh sebab itu pengendalian material sangat diperlukan.

Dalam melakukan pengadaan material konstruksi, kendala yang umumnya terjadi adalah material yang dipesan belum tiba atau terlambat datang. Semenjak material tersebut dipesan hingga tiba di lokasi proyek, terdapat selang waktu menunggu. Waktu menunggu pesanan adalah waktu antara atau tenggang waktu sejak pesanan dilakukan sampai dengan saat pesanan tersebut masuk ke gudang (Prawirosentono, 2000). Waktu tunggu material konstruksi dapat dipengaruhi oleh jarak antara proyek yang membutuhkan material dengan pemasok material. Semakin jauh jaraknya, maka waktu tunggu akan relatif lebih lama.

Dalam Pelaksanaan proyek konstruksi, kelancaran aliran material menuju lokasi proyek sangat penting. Hambatan akibat tidak tersedianya material menyebabkan tertundanya pekerjaan-pekerjaan yang telah dijadwalkan sebelumnya. Menunggu material yang sering terjadi akan menyebabkan dampak yang besar terutama untuk proyek skala besar yang menggunakan banyak tenaga kerja. Jika kedatangan material yang diperlukan tidak sesuai jadwal pengadaan material rencana, akan menyebabkan tenaga kerja tersebut menganggur sehingga biaya proyek akan membengkak serta terlambatnya waktu penyelesaian proyek. Untuk mengetahui penyebab waktu tunggu perlu dilakukan penelitian mengenai faktor-faktor yang mempengaruhi waktu tunggu pengadaan material konstruksi.

\section{Rumusan Masalah}

Apa saja faktor-faktor yang mempengaruhi waktu tunggu pengadaan material konstruksi serta faktor dominannya pada proyek gedung di Kabupaten Badung.?

\section{Tujuan Penelitian}

Mengetahui faktor-faktor yang mempengaruhi waktu tunggu pengadaan material konstruksi serta faktor dominannya pada proyek gedung di Kabupaten Badung.

\section{TINJAUAN PUSTAKA \\ Material dalam Proyek Konstruksi}

Semua bahan yang dibutuhkan untuk menyelesaikan satu kesatuan pekerjaan pada suatu proses konstruksi disebut dengan material konstruksi (Ibrahim, 2007).

Terdapat dua jenis material (bahan) konstruksi :

1. Bahan permanen

Bahan permanen adalah bahan yang menjadi bagian dari bangunan dan dijelaskan dengan rinci dalam dokumen kontrak (gambar kerja dan spesifikasi).

2. Bahan sementara

Bahan sementara adalah bahan yang tidak menjadi bagian dari bangunan (disingkirkan) setelah digunakan.

\section{Manajemen Material}

Untuk menyelesaikan permasalahan material diperlukan suatu pendekatan organisasional berupa kombinasi antara kemampuan manajerial dan teknis, atau disebut dengan manajemen material (Ervianto, 2004). Dalam manajemen material terdapat beberapa proses yang dilewati yaitu :

1. Pemilihan Bahan

Dalam memilih bahan, harus sesuai dengan spesifikasi yang telah ditentukan kecuali ada persetujuan untuk melakukan perubahan.

2. Pemilihan Pemasok Bahan

Dalam memilih pemasok, biasanya dilihat dari harga yang ditawarkan. Tapi selain itu juga harus diperhatikan kualitas dari pemasok seperti keandalan pemasok, kualitas layanan, kualitas bahan yang dimiliki dan ukuran pemasok.

3. Pembelian Bahan

Kontraktor sebagai pelaksana suatu proyek seringkali terlibat dalam sejumlah proyek dengan lokasi yang berbeda-beda. Untuk mengatasi permasalahan tersebut, pembelian bahan dapat dilakukan dengan 2 cara yaitu basis terpusat dan basis lokal.

4. Pengiriman Bahan

Pengiriman bahan dilakukan setelah dilakukan pengecekan apakah material yang akan dikirim sudah sesuai dengan pesanan.

5. Penerimaan Bahan

Pada saat bahan diterima, harus dilakukan pengecekan apakah bahan tersebut 
benar-benar bahan yang dipesan, biasanya dilakukan oleh petugas gudang.

6. Penyimpanan Bahan

Bahan yang diterima biasanya disimpan di gudang. Petugas gudang memiliki tanggung jawab menjaga bahan hingga bahan tersebut dikeluarkan dari gudang.

7. Pengeluaran Bahan

Gudang merupakan sumber pertama dalam memenuhi kebutuhan proyek. Untuk mengeluarkan bahan dari gudang biasanya petugas gudang membuat berita acara yang mengandung informasi seperti jenis bahan dan tujuan penggunaan bahan.

\section{Rantai Pasok (Supply Chain) dalam Proyek Konstruksi}

Menurut Djokopranoto dan Indrajit (2009), suatu sistem tempat organisasi menyalurkan barang produksi dan jasanya kepada customer disebut dengan rantai pasok. Dalam dunia proyek konstruksi, rantai pasok dapat diartikan sebagai suatu istilah yang digunakan untuk menjelaskan hubungan dari organisasi-organisasi atau perusahaanperusahaan dalam kaitannya terhadap perubahan suatu material dasar, barang atau jasa menjadi sebuah barang jadi berupa bangunan konstruksi seperti gedung, jalan, jembatan dan lainnya bagi pelanggan.

Dalam melihat persoalan logistik, rantai pasok adalah konsep baru. Logistik dalam konsep lama dilihat lebih sebagai persoalan internal perusahaan dalam mengelola material dan pemecahannya difokuskan pada pemecahan secara internal di masing-masing perusahaan. Sedangkan dalam konsep baru, masalah logistik dipandang sebagai masalah yang lebih luas yang terbentang sejak dari bahan dasar sampai barang jadi yang dipakai oleh konsumen akhir.

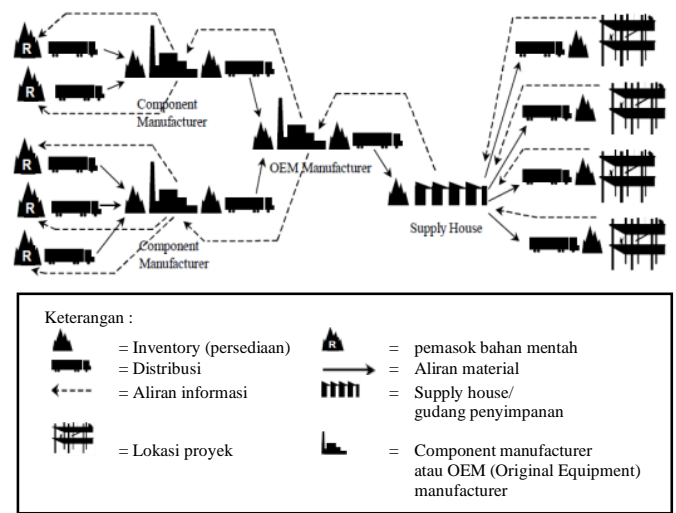

Gambar 1.Contoh rantai pasok pada konstruksi (Sumber : Taylor and Bjornsson, 1999)

\section{Waktu Tunggu Material Konstruksi}

Menurut Prawirosentono (2000), selang waktu sejak material dipesan hingga tiba di lokasi tujuan disebut waktu menunggu pesanan. Waktu tunggu adalah cenderung berubah-ubah, dapat dipengaruhi oleh cuaca, spesifikasi material, dan lain sebagainya. Dalam suatu proyek, tujuan material sejak dilakukan order tidak selalu gudang penyimpanan. Material dapat langsung dikirim ke lokasi proyek tanpa melalui gudang bila memang dibutuhkan segera dan tersedia ruang penempatan yang cukup untuk material tersebut. Ada beberapa faktor yang mempengaruhi waktu tunggu material konstruksi yaitu (Ekaputra, 2001):

a. Proses produksi material pada pemasok

Dalam proyek konstruksi, terdapat material yang membutuhkan proses pabrikasi terlebih dahulu sebelum dapat didatangkan. Salah satu material tersebut adalah beton pracetak. dimana bila terjadi hambatan pada proses produksi maka akan menyebabkan waktu tunggu material bertambah lama.

b. Kurangnya stock material pada pemasok

Bila jumlah pesanan melebihi jumlah stock material yang tersedia pada pemasok maka kedatangan material akan lebih lama karena menunggu pemenuhan material yang kurang tersebut.

c. Ketersediaan alat angkut transportasi material

Alat angkut dibutuhkan untuk mendistribusikan material menuju lokasi proyek. Jumlah alat angkut yang memadai sangat penting untuk dapat melayani pengiriman material terutama jika pesanan yang diperoleh banyak dan lokasinya saling berjauhan.

d. Kelancaran pembayaran oleh kontraktor

Kelancaran pembayaran dapat menjadi penyebab tertundanya kedatangan material. Bila kontraktor belum melakukan pembayaran meskipun material telah tiba untuk waktu yang lama maka menyebabkan kekhawatiran terhadap pemasok. Untuk menekan kontraktor, pemasok sering kali sengaja menahan material sampai kontraktor melunasi pembayaran pesanan terdahulu.

e. Jenis material yang dipesan

Material yang digunakan dalam proyek konstruksi adalah beraneka ragam contohnya keramik, pasir, semen, cat, besi tulangan, dan kayu. Material yang umum terdapat di pasaran seperti pasir akan lebih mudah didatangkan dan tidak memerlukan waktu yang lama. Sedangkan material yang langka di pasaran 
akan memerlukan waktu yang lebih lama untuk mendatangkannya.

f. Spesifikasi Material

Material konstruksi juga memiliki spesifikasi yang bermacam-macam. Misalnya besi tulangan memiliki beberapa ukuran diantaranya diameter $10 \mathrm{~mm}, 16 \mathrm{~mm}$, dan 32 mm. Keramik memiliki lebih banyak spesifikasi mulai dari yang ukuran kecil hingga besar serta pilihan motif yang beraneka warna. Dalam pelaksanaan proyek, spesifikasi material yang digunakan dapat mempengaruhi waktu tunggu karena jika material tersebut sulit dicari maka menyebabkan waktu tunggu pengadaan menjadi relatif lebih lama.

g. Ketersediaan ruang untuk penempatan/ penyimpanan material konstruksi

Dalam mendatangkan material konstruksi harus memperhatikan ketersediaan ruang. Jika ruang penempatan kecil atau sempit maka jumlah material yang dapat didatangkan juga sedikit, sehingga bila suatu proyek membutuhkan jumlah material yang banyak, proses pengadaan akan terhambat karena dibatasi oleh kapasitas ruang penempatan material yang sedikit.

h. Kurangnya koordinasi dan komunikasi antara divisi-divisi yang terkait dengan proses pengadaan material

Terdapat beberapa divisi yang memiliki keterkaitan dalam pengadaan material yaitu divisi bidang teknik dan administrasi kontrak, bidang logistik, dan bidang pelaksanaan. Koordinasi dan komunikasi yang baik antara divisi-divisi tersebut akan melancarkan proses pengadaan material konstruksi.

\section{i. Kualitas staf pengadaan}

Kualitas staf pengadaan dapat mempengaruhi proses pengadaan material. Jika kualitas staf kurang memadai, akan berakibat banyaknya terjadi kesalahan-kesalahan sepertid kesalahan dalam membaca mutu material sehingga material yang datang tidak seusai pesanan.

j. Jumlah staf yang kurang sehingga kontrol terhadap pemasok kurang diperhatikan.

Dalam proyek skala besar yang membutuhkan banyak jenis material, perlu dilakukan kontrol terhadap pemasok. Kontrol tersebut berkaitan dengan ketepatan waktu pengiriman yang dilakukan pemasok.

k. Kecelakaan pada saat pengiriman material.

Kecelakan dapat terjadi karena kondisi jalan yang kurang baik atau akibat kondisi kendaraan angkut material yang sudah tidak laik jalan.
1. Cuaca buruk

Cuaca buruk seperti badai dapat menjadi salah satu penyebab keterlambatan material terutama bila alat angkut yang digunakan adalah kapal laut.

m. Bencana alam

Tanah longsor merupakan salah satu bencana alam yang dapat mengganggu distribusi material. Hal ini sering terjadi pada jalan-jalan yang melewati medan perbukitan.

n. Pemogokan buruh

Pemogokan dapat disebabkan karena adanya tuntutan pemenuhan kebutuhan para pekerja seperti kenaikan gaji. Hal ini dapat menyebabkan terhambatnya produksi materialmaterial yang memerlukan tenaga buruh.

o. Pengadaan material yang diatur oleh pemilik proyek.

Dalam proyek dengan sistem swakelola, pihak owner memiliki kewenangan penuh dalam penentuan material yang digunakan. Pengadaan material bisa terlambat bila harus menunggu persetujuan owner terhadap sampel material yang digunakan sehingga akan memperlambat pelaksanaan pekerjaan.

p. Kenaikan Harga Material

Fluktuasi harga material dapat dipengaruhi salah satunya oleh kondisi ekonomi negara. Kenaikan harga material yang tinggi akan membuat pihak kontraktor menunda pengadaan material. Penundaan bertujuan untuk melakukan penyesuaian harga, sehingga dapat dihindari kerugian akibat selisih harga yang besar.

\section{Teknik Sampling}

Pada dasarnya, teknik sampling bisa dikelompokkan menjadi dua yaitu probability sampling dan nonprobability sampling (Sugiyono, 2010). Probability sampling adalah teknik pengambilan sampel yang memberikan peluang yang sama bagi setiap unsur (anggota) populasi untuk dipilih menjadi anggota sampel. Sedangkan nonprobability sampling adalah sebaliknya, yaitu tidak memberi peluang/ kesempatan sama bagi setiap unsur atau anggota populasi untuk dipilih menjadi sampel.

Teknik sampling yang digunakan penelitian ini adalah purposive sampling dari kelompok nonprobability Sampling. Purposive sampling adalah teknik penentuan sampel dengan pertimbangan tertentu.

\section{Skala Pengukuran Pada Instrumen Penelitian}

Skala likert adalah skala pengukuran yang digunakan pada instrumen penelitian. 
Skala Likert merupakan salah satu skala yang paling banyak digunakan pada penelititan sosial (Morissan, 2012). Penggunaan skala likert menggambarkan tingkat kesetujuan atau ketidaksetujuan terhadap masing-masing pernyataan pada kuesioner. Skor dimulai dari 1 untuk Sangat Rendah (SR), 2 untuk Rendah (R), 3 untuk Sedang (S), 4 untuk Tinggi (T), dan 5 untuk Sangat Tinggi (ST).

\section{Instrumen Penelitian}

\section{A. Uji Validitas}

Uji validitas menggunakan teknik

korelasi pearson product moment dengan bantuan software SPSS.

$$
\mathrm{r}_{\mathrm{xy}}=\frac{N \sum x_{i} y_{i}-\left(\sum x_{i}\right)\left(\sum y_{i}\right)}{\sqrt{\left[N\left(\sum x_{i}^{2}-\left(\sum x_{i}\right)^{2}\right)\left(N \sum y_{i}^{2}-\left(\sum y_{i}\right)^{2}\right)\right]}}
$$

Di mana :

$\mathrm{r}_{\mathrm{xy}}=$ koefisien korelasi Pearson Product Moment atau nilai validitas

$N=$ jumlah responden

$\sum \mathrm{x}_{\mathrm{i}} \mathrm{y}_{\mathrm{i}}=$ jumlah perkalian skor butir dan skor variabel

$\sum \mathrm{x}_{\mathrm{i}}^{2}=$ jumlah skor butir pertanyaan kuadrat

$\sum \mathrm{y}_{\mathrm{i}}^{2}=$ jumlah skor variabel kuadrat

$\sum \mathrm{x}_{\mathrm{i}}=$ jumlah skor butir pertanyaan

$\sum \mathrm{y}_{\mathrm{i}} \quad=$ jumlah skor variabel

Koefisien korelasi product moment termasuk valid jika nilainya $>r_{\text {tabel }}$ (Priyatno, 2010).

\section{B. Uji Realibilitas}

Uji Reliabilitas bertujuan untuk mengukur konsistensi alat ukur. Metode penilaian yang digunakan adalah Alpha Cronbach, yaitu (Arikunto, 2006):

$$
r_{11}=\left(\frac{k}{k-1}\right)\left(1-\frac{\sum S_{i}}{S_{t}}\right)
$$

keterangan :

$$
\begin{array}{ll}
r_{11} & =\text { nilai reliabilitas } \\
S_{i} & =\text { jumlah varians skor tiap item } \\
S_{t} & =\text { jumlah varians } \\
k & =\text { jumlah item }
\end{array}
$$

\section{Analisis Faktor}

Analisis faktor termasuk dalam statistik Multivariate yang bertujuan untuk mereduksi data. Proses analisis faktor digunakan untuk menemukan hubungan antara variabel yang saling independen yang kemudian dikelompokkan menjadi beberapa kelompok, sehingga bisa terbentuk satu atau beberapa kumpulan variabel yang lebih sedikit dari jumlah variabel awal (Santoso, 2010). faktor :

Berikut adalah langkah-langkah analisis

1. Memilih variabel yang layak untuk analisis faktor

Pemilihan variabel dilakukan dengan melihat nilai $\mathrm{KMO}>0,5$ dan $\mathrm{MSA}>0,5$. Bila ada variabel yang memiliki MSA $<0,5$ maka dikeluarkan dari analisis.

2' Susun ekstrasi variabel

Setelah sejumlah variabel terpilih, maka dilakukan ekstraksi variabel menjadi beberapa kelompok faktor, dengan menggunakan metode PCA (Principal Component Analysis). Nilai eigen value $\geq 1$ digunakan dalam menentukan jumlah kelompok faktor yang terbentuk.

3. Rotasi Kelompok Faktor

Suatu variabel akan masuk kesuatu kelompok faktor berdasarkan loading factor terbesar yang dimiliki. Rotasi faktor bertujuan untuk memperjelas distribusi varibel kedalam kelompok faktor. Rotasi faktor menggunakan metode varimax.

4. Menamakan Kelompok Faktor

Penamaan kelompok faktor bersifat subyektif, tergantung dari variabel yang membentuknya.

\section{METODE PENELITIAN \\ Pendekatan Penelitian}

Model pendekatan yang diterapkan dalam penelitian ini adalah pendekatan kualitatif. Penelitian ini menggunakan kuesioner yang akan disebarkan ke masingmasing responden sehingga diperoleh hasil berupa tanggapan atas permasalahan yang diangkat dalam penelitian.

\section{Lokasi Penelitian}

Penelitian ini diadakan di Kabupaten Badung. Lokasi ini dipilih karena Kabupaten Badung merupakan salah satu wilayah di Bali yang banyak terdapat proyek konstruksi skala besar.

\section{Jenis dan Sumber Data}

Jenis data yang dikumpulkan dalam penelitian ini adalah data kualitatif yaitu berupa data primer yang diperoleh langsung dari hasil survei menggunakan kuesioner dan wawancara. 


\section{Teknik Sampling dan Jumlah Sampel}

Teknik sampling yang digunakan dalam penelitian ini adalah purposive sampling.

Berdasarkan pertimbangan bahwa semakin besar nilai proyek maka jumlah dan jenis material yang digunakan juga semakin banyak. Permasalahan material akan lebih banyak dijumpai pada proyek-proyek berskala besar. Proyek yang ditinjau dalam penelitian ini adalah yang memiliki nilai minimal 10 miliar rupiah.

Sampel yang digunakan dalam penelitian ini adalah sebanyak 50 sampel Sampel tersebut merupakan para ekspert yang bekerja pada proyek-proyek konstruksi gedung di Kabupaten Badung.

\section{Teknik Pengumpulan Data dan Analisis Data}

Untuk menyelesaikan penelitian ini diperlukan beberapa tahapan yaitu :

1. Menyusun faktor-faktor yang mempengaruhi waktu tunggu material konstruksi gedung melalui metode brainstorming, studi literatur, dan pengalaman peneliti.

2. Penyusunan Kuesioner Penelitian.

Hasil penyusunan faktor-faktor tersebut kemudian digunakan untuk menyusun pernyataan-pernyataan yang akan dituangkan ke dalam kuesioner.

3. Uji validitas dan reliabilitas kuesioner penelitian.

Sebelum kuesioner disebarkan kepada para responden, terlebih dahulu dilakukan uji validitas dan reliabilitas kuesioner. Sampel yang digunakan untuk uji validitas dan reliabilitas adalah 30 responden.

4. Pengumpulan Data Penelitian.

Setelah kuesioner valid dan reliabel, langkah selanjutnya adalah penyebaran kuesioner kepada responden.

\section{Analisis Data}

Data yang telah terkumpul kemudian diolah sesuai tujuan penelitian. Analisis data yang digunakan adalah analisis faktor.

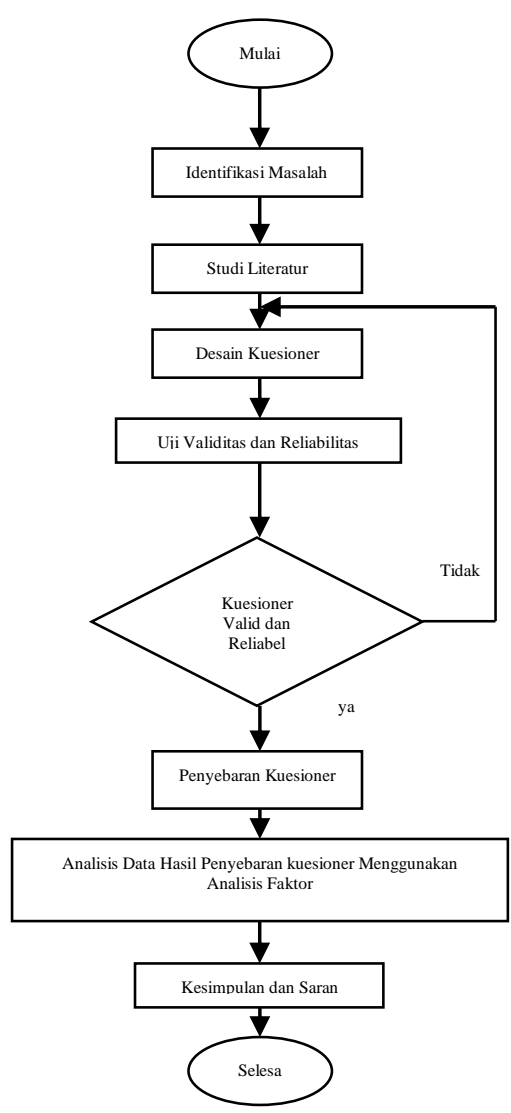

Gambar 2. Diagram Alir Penelitian

\section{HASIL DAN PEMBAHASAN Identifikasi Faktor}

Hasil identifikasi faktor awal berdasarkan brainstorming dan literatur diperoleh dua puluh enam variabel. Faktorfaktor tersebut kemudian digunakan dalam membuat kuesioner.

\section{Uji Validitas dan Reliabilitas}

Sebelum digunakan, kuesioner terlebih dahulu diuji validitas dan reliabilitasnya. Berdasarkan hasil perhitungan, kedua puluh enam variabel yang dituangkan kedalam kuesioner telah valid dan reliabel sehingga dapat digunakan sebagai alat ukur penelitian.

\section{Pengumpulan Data Penelitian}

Data penelitian diperoleh dari hasil penyebaran kuesioner dan wawancara kepada 50 orang responden yang bekerja pada proyekproyek konstruksi gedung di kabupaten Badung.

\section{Hasil Analisis Faktor}

Analisis faktor dalam penelitian ini dilakukan sebanyak 3 kali karena ada beberapa variabel yang nilai MSA dan loading faktor 
tidak memenuhi syarat. Proses perhitungan analisis faktor tersebut adalah sebagai berikut :

\section{Analisis faktor ke-1}

Pada analisis faktor ke-1 diperoleh nilai KMO sebesar 0,674 sudah memenuhi syaratnya yaitu $>0,5$. Begitu juga dengan nilai Bartlett's Test of Sphericity adalah Significance sebesar 0,000 sudah memenuhi syarat $<0,005$. Analisis terhenti pada hasil perhitungan nilai MSA. Variabel $\mathrm{X}_{22}$ (Bencana alam) memiliki nilai MSA $<0,5$ yaitu sebesar 0,457 , sehingga $X_{22}$ dikeluarkan dan analisis faktor diulang.

\section{Analisis faktor ke-2}

Pada analisis faktor ke-2, jumlah variabel yang diikutsertakan adalah sebanyak 25 variabel. Nilai KMO yang diperoleh adalah sebesar 0,738. Nilai MSA masing-masing variabel telah memenuhi syarat yaitu > 0,5 sehingga analisis dapat dilanjutkan.

Dengan menggunakan metode Principal Component Analysis (PCA) diperoleh 7 faktor yang mempengaruhi waktu tunggu pengadaan material konstruksi pada proyek-proyek gedung di Kabupaten Badung. Ketujuh faktor tersebut dapat menjelaskan semua varian yang ada dalam data, yaitu sebesar 75,475 persen.

Tabel 1. Hasil ekstraksi variabel untuk penentuan jumlah faktor

\begin{tabular}{|c|c|c|c|}
\hline Faktor & Eigenvalue & $\begin{array}{c}\text { Percent of } \\
\text { Variance }\end{array}$ & $\begin{array}{c}\text { Commulative } \\
\text { of variance }\end{array}$ \\
\hline 1 & 8.991 & 35.962 & 35.962 \\
\hline 2 & 2.564 & 10.255 & 46.217 \\
\hline 3 & 2.186 & 8.744 & 54.961 \\
\hline 4 & 1.661 & 6.645 & 61.606 \\
\hline 5 & 1.246 & 4.984 & 66.589 \\
\hline 6 & 1.211 & 4.845 & 71.434 \\
\hline 7 & 1.010 & 4.041 & 75.475 \\
\hline
\end{tabular}

Langkah selanjutnya adalah rotasi faktor yang bertujuan untuk memperjelas distribusi kedua puluh lima variabel tersebut pada tujuh faktor yang terbentuk yang ditentukan oleh angka loading factor. Angka loading factor menunjukkan besar korelasi antara suatu variabel dengan faktor yang terbentuk. Syarat angka loading faktor adalah $>0,5$. Dari hasil rotasi, ada 2 variabel yang tidak memenuhi syarat yaitu $\mathrm{X}_{5}$ (Jenis alat angkut yang digunakan dalam proses pengiriman material) sebesar 0,447 dan $\mathrm{X}_{10}$ (Spesifikasi Material) sebesar 0,464. Oleh karena itu variabel yang memiliki angka loading factor terkecil $\left(\mathrm{X}_{5}\right)$ dikeluarkan dan analisis faktor diulang dari awal.

\section{Analisis faktor ke-3}

Pada analisis faktor ke-3, jumlah variabel yang diikutsertakan adalah sebanyak 24 variabel. Nilai KMO yang diperoleh adalah sebesar 0,739. Nilai MSA masing-masing variabel telah memenuhi syarat yaitu > 0,5 sehingga analisis dapat dilanjutkan.

Dengan menggunakan metode Principal Component Analysis (PCA) diperoleh 7 faktor yang mempengaruhi waktu tunggu pengadaan material konstruksi pada proyek gedung di Kabupaten Badung. Ketujuh faktor tersebut dapat menjelaskan semua varian yang ada dalam data, yaitu sebesar 76,203 persen

Tabel 2. Hasil ekstrasi variabel uji faktor ke-tiga

\begin{tabular}{|c|c|c|c|}
\hline Faktor & Eigenvalue & $\begin{array}{c}\text { Percent of } \\
\text { Variance }\end{array}$ & $\begin{array}{c}\text { Commulative } \\
\text { of variance }\end{array}$ \\
\hline 1 & 8.519 & 35.495 & 35.495 \\
\hline 2 & 2.557 & 10.652 & 46.148 \\
\hline 3 & 2.150 & 8.957 & 55.104 \\
\hline 4 & 1.660 & 6.917 & 62.021 \\
\hline 5 & 1.245 & 5,189 & 67.210 \\
\hline 6 & 1.157 & 4.821 & 72.031 \\
\hline 7 & 1.001 & 4.171 & 76.203 \\
\hline
\end{tabular}

Tahapan berikutnya adalah rotasi faktor. Hasil rotasi faktor menunjukkan semua variabel memiliki angka loading factor > 0,5 yaitu memiliki korelasi yang kuat terhadap faktor yang terbentuk. Distribusi kedua puluh empat variabel tersebut pada tujuh faktor yang terbentuk adalah sebagai berikut :

a. Kelompok Faktor Pertama

Faktor ini memiliki eigen value sebesar 8,519 dan memiliki variance sebesar 35,495 persen. Faktor ini dibentuk oleh 6 variabel, yaitu:

- Proses produksi material pada pemasok $\left(\mathrm{X}_{2}\right)$ dengan loading factor sebesar 0,835

- Relasi antara kontraktor dan pemasok $\left(\mathrm{X}_{1}\right)$ dengan loading factor 0,789

- Kurangnya stock material pada pemasok $\left(\mathrm{X}_{3}\right)$ dengan loading factor 0,714

- Ketersediaan alat angkut transportasi material $\left(\mathrm{X}_{4}\right)$ dengan loading factor 0,697

- Akses menuju proyek $\left(\mathrm{X}_{12}\right)$ dengan loading factor 0,681

- Kondisi topografi yang ekstrim $\left(X_{13}\right)$ dengan loading factor 0,539

b. Kelompok Faktor Kedua

Faktor ini memiliki eigen value sebesar 2,557 dan memiliki variance sebesar 10,652 persen. Faktor ini dibentuk oleh 3 variabel, yaitu: 
- Cuaca buruk $\left(\mathrm{X}_{21}\right)$ dengan loading factor sebesar 0,805

- Kecelakaan pada saat pengiriman material $\left(\mathrm{X}_{19}\right)$ dengan loading factor sebesar 0,701

- Kenaikan Harga BBM (Bahan Bakar Minyak) $\left(\mathrm{X}_{23}\right)$ dengan loading factor 0,686

c. Kelompok Faktor Ketiga

Faktor ini memiliki eigen value sebesar

2,150 dan memiliki variance sebesar 8,957 persen. Kelompok Faktor ini dibentuk oleh 4 variabel, yaitu:

- Jumlah material yang dipesan $\left(X_{7}\right)$ dengan loading factor sebesar 0,763

- Jenis material yang dipesan $\left(\mathrm{X}_{9}\right)$ dengan loading factor sebesar 0,753

- Ketersediaan ruang untuk penempatan/ penyimpanan material konstruksi $\left(\mathrm{X}_{14}\right)$ dengan loading factor sebesar 0,702

- Kelancaran pembayaran oleh kontraktor $\left(\mathrm{X}_{6}\right)$ dengan loading factor sebesar 0,594.

d. Kelompok Faktor Keempat

Faktor ini memiliki eigen value sebesar 1,660 dan memiliki variance sebesar 6,917 persen. Kelompok faktor ini dibentuk oleh 4 variabel, yaitu:

- Kualitas staf pengadaan $\left(\mathrm{X}_{16}\right)$ dengan loading factor sebesar 0,793

- Demand (permintaan) pasar terhadap material $\left(\mathrm{X}_{8}\right)$ dengan loading factor sebesar 0,617

- Pengadaan material yang diatur oleh pemilik proyek $\left(\mathrm{X}_{25}\right)$ dengan loading factor sebesar 0,598

- Spesifikasi Material $\left(\mathrm{X}_{10}\right)$ dengan loading factor sebesar 0,511.

e. Kelompok Faktor Kelima

Faktor ini memiliki eigen value sebesar 1,245 dan memiliki variance sebesar 5,189 persen. Faktor ini dibentuk oleh 3 variabel, yaitu:

- Kurangnya koordinasi dan komunikasi antara divisi-divisi yang terkait dengan proses pengadaan material $\left(\mathrm{X}_{15}\right)$ dengan loading factor sebesar 0,779

- Jumlah staf yang kurang sehingga kontrol terhadap pemasok kurang diperhatikan $\left(\mathrm{X}_{17}\right)$ dengan loading factor sebesar 0,726

- Sistem pengadaan yang digunakan $\left(X_{18}\right)$ dengan loading factor sebesar 0,641.

f. Kelompok Faktor Keenam

Faktor ini memiliki eigen value sebesar 1,157 dan memiliki variance sebesar 4,821 persen. Kelompok Faktor ini dibentuk oleh 2 variabel, yaitu:

- Pemogokan buruh $\left(\mathrm{X}_{24}\right)$ dengan loading factor sebesar 0,806
- Kenaikan Harga Material $\left(\mathrm{X}_{26}\right)$ dengan loading factor sebesar 0,585.

g. Kelompok Faktor Ketujuh

Faktor ini memiliki eigen value sebesar 1,001 dan memiliki variance sebesar 4,171 persen. Kelompok Faktor ini dibentuk oleh 2 variabel, yaitu:

- Jarak antara lokasi proyek dengan pemasok $\left(\mathrm{X}_{11}\right)$ dengan loading factor sebesar 0,835

- Kepadatan lalu lintas $\left(\mathrm{X}_{20}\right)$ dengan loading factor sebesar 0,780.

Faktor yang terbentuk diberikan nama faktor I, faktor II, faktor III, faktor IV, faktor V, faktor VI dan faktor VII. Faktor I memiliki nilai percent of variance terbesar diantara ketujuh faktor tersebut yaitu sebesar 35,495\%. Artinya adalah varian (keragaman) seluruh variabel penelitian dapat dijelaskan oleh faktor I sebanyak $35,495 \%$. Oleh karena itu faktor I merupakan faktor dominan yang mempengarui waktu tunggu pengadaan material konstruksi pada proyek gedung di Kabupaten Badung.

\section{SIMPULAN DAN SARAN Simpulan}

Dari hasil penelitian dan pembahasan yang telah dilakukan, dapat disimpulkan sebagai berikut :

1. Ada tujuh faktor yang mempengaruhi waktu tunggu pengadaan material konstruksi pada proyek gedung di kabupaten Badung. Ketujuh faktor tersebut adalah :

a. Faktor I yang terdiri dari :

- Proses produksi material pada pemasok

- Relasi antara kontraktor dan pemasok

- Kurangnya stock material pada pemasok

- Ketersediaan alat angkut transportasi material

- Akses menuju proyek

- Kondisi topografi yang ekstrim.

b. Faktor II yang terdiri dari :

- Cuaca buruk

- Kecelakaan pada saat pengiriman material

- Kenaikan Harga BBM (Bahan Bakar Minyak).

c. Faktor III yang terdiri dari :

- Jumlah material yang dipesan

- Jenis material yang dipesan

- Ketersediaan ruang untuk penempatan/ penyimpanan material konstruksi 
- Kelancaran pembayaran oleh kontraktor.

d. Faktor IV yang terdiri dari:

- Kualitas staf pengadaan

- Demand (permintaan) pasar terhadap material

- Pengadaan material yang diatur oleh pemilik proyek

- Spesifikasi Material.

e. Faktor V yang terdiri dari:

- Kurangnya koordinasi dan komunikasi antara divisi-divisi yang terkait dengan proses pengadaan material

- Jumlah staf yang kurang sehingga kontrol terhadap pemasok kurang diperhatikan

- Sistem pengadaan yang digunakan.

f. Faktor VI yang terdiri dari:

- Pemogokan buruh

- Kenaikan Harga Material

g. Faktor VII yang terdiri dari:

- Jarak antara lokasi proyek dengan pemasok

- Kepadatan lalu lintas.

2. Faktor dominan yang mempengaruhi waktu tunggu pengadaan material konstruksi pada proyek gedung di Kabupaten Badung adalah faktor I karena memiliki angka percent of variance terbesar yaitu 35,495 persen, yang terdiri dari :

a) Proses produksi material pada pemasok

b) Relasi antara kontraktor dan pemasok

c) Kurangnya stock material pada pemasok

d) Ketersediaan alat angkut transportasi material

e) Akses menuju proyek

f) Kondisi topografi yang ekstrim.

\section{Saran}

Adapun saran yang dapat diberikan dalam penelitian ini adalah sebagai berikut :

1. Dalam melakukan pengadaan material sebaiknya pihak kontraktor memperhatikan keenam faktor dominan yang mempengaruhi waktu tunggu pengadaan material sehingga dapat dilakukan langkahlangkah yang tepat untuk mengurangi gangguan pelaksanaan proyek akibat sering terjadinya peristiwa menunggu material.

2. Perlu dilakukan penelitian lebih lanjut untuk mengetahui faktor-faktor yang mempengaruhi waktu tunggu pengadaan material konstruksi supply by owner yang ada pada suatu proyek konstruksi.
DAFTAR PUSTAKA

Arikunto, S. 2006. Manajemen Penelitian. Cetakan ketujuh. Jakarta: PT. Asdi Mahasatya.

Djokopranoto, R. dan Indrajit, R. E.. 2009. Konsep Manajemen Supply Chain. Jakarta : PT. Grasindo.

Ekaputra, J.. 2001. Sebuah model penjadwalan dan pengendalian material dalam pelaksanaan proyek konstruksi. Master thesis, Petra Christian University.

Ervianto, W. I.. 2004. Teori Aplikasi Manajemen Proyek Konstruksi. Yogyakarta : ANDI.

Ibrahim, H. B.. 2007. Rencana dan Estimate Real of Cost. Jakarta : Bumi Aksara.

Morissan, M.A.. 2012. Metode Penelitian Survei. Jakarta: Kencana Prenada Media Group.

Prawirosentono, S.. 2000. Manajemen Operasi Analisis dan Studi Kasus Edisi Kedua. Bumi Aksara; Jakarta.

Priyatno, D. 2010. Paham Analisa Statistik Data dengan SPSS. Yogyakarta: MediaKom.

Santoso, S.. 2010. Statistik Multivariat Konsep dan Aplikasi dengan SPSS. Jakarta: PT. Elex Media Komputindo.

Sugiyono. 2010. Statistika Untuk Penelitian. Cetakan ke-16. Bandung: Alfabeta.

Taylor, J. and Bjornsson, H.. 1999. Construction Supply Chain ImprovementsThrough Internet Pooled Procurement. University of California, Berkeley, CA, USA. 